\title{
Rothia aeria: a great mimicker of the Nocardia species
}

\author{
Takeshi Saraya, ${ }^{1}$ Shota Yonetani, ${ }^{2}$ Yukari Ogawa, ${ }^{1}$ Yasutaka Tanaka ${ }^{1}$
}

${ }^{1}$ Department of Respiratory Medicine, Kyorin University, Mitaka, Japan

${ }^{2}$ Department of Laboratory Medicine, Kyorin University, Mitaka, Japan

\section{Correspondence to Dr Takeshi Saraya, sara@yd5.so-net.ne.jp}

Accepted 18 November 2014
CrossMark

To cite: Saraya $T$, Yonetani S, Ogawa Y, et al. BMJ Case Rep Published online: [please include Day Month Year] doi:10.1136/ bcr-2014-206349

\section{DESCRIPTION}

An 80-year-old man was admitted to our hospital with a 2-week history of an exaggerated productive cough. He had type 2 diabetes mellitus (glycated haemoglobin 8.1\%), pancreatic cancer (cT2aN0M1, stage IB) and allergic bronchopulmonary aspergillosis (ABPA) for the past few years. He was treated with antihyperglycaemic drugs and prednisolone $(10 \mathrm{mg} /$ day) for ABPA. No pathogens were noted on bronchial lung washing, and his condition gradually improved. However, his sputum Gram stain newly demonstrated abundant Gram-positive filamentous bacteria (figure 1A). Furthermore, $48 \mathrm{~h}$ after incubation of sputum with 5\% sheep's blood agar (Eiken Chemical, Tokyo, Japan) at $37^{\circ} \mathrm{C}$ under $5 \%$ $\mathrm{CO}_{2}$, smooth, very small white colonies appeared and when mature they were rough, dry, folded convex and adhered to the blood agar; these were identified as Rothia aeria using Matrix-Assisted Laser Desorption/Ionisation-Time of Flight Mass Spectrometry (MALDI-Tof-MS). R. aeria was first isolated from an air and water sampler in Russia's Mir space station ${ }^{1}$ and has been detected in the mouths of healthy individuals. ${ }^{2}$ It can be mistaken for Nocardia spp (figure 1B, presented as control) due to the morphological similarities, and discrimination between $R$ aeria and Nocardia spp needs further analyses, such as MALDI-Tof-MS and/or 16S rRNA. $R$. aeria rarely causes respiratory infections, ${ }^{3}$ but it should be considered in the differential diagnosis of Nocardia spp, especially in immunocompromised patients who are vulnerable to Nocardia infections.

\section{Learning points}

- Rothia aeria is a Gram-positive filamentous bacterium that can colonise in healthy individuals.

- $R$. aeria rarely causes respiratory infections, but it should be differentiated from Nocardia spp.

- The discrimination between Nocardia spp and Rothia aeria needs further analyses using MALDI-Tof-MS and/or $16 \mathrm{~S}$ rRNA.

Contributors TS, YO and YT managed the patient. SY performed microbiological analysis.

Competing interests None.

Patient consent Obtained.

Provenance and peer review Not commissioned; externally peer reviewed.

\section{REFERENCES}

1 Li Y, Kawamura Y, Fujiwara N, et al. Rothia aeria sp. nov., Rhodococcus baikonurensis sp. nov. and Arthrobacter russicus sp. nov., isolated from air in the Russian space laboratory Mir. Int J Syst Evol Microbiol 2004;54(Pt 3):827-35.

2 von Graevenitz A, Punter-Streit V, Riegel P, et al. Coryneform bacteria in throat cultures of healthy individuals. J Clin Microbiol 1998;36:2087-8

3 Michon J, Jeulin D, Lang JM, et al. Rothia aeria acute bronchitis: the first reported case. Infection 2010;38:335-7. 
Copyright 2014 BMJ Publishing Group. All rights reserved. For permission to reuse any of this content visit http://group.bmj.com/group/rights-licensing/permissions.

BMJ Case Report Fellows may re-use this article for personal use and teaching without any further permission.

Become a Fellow of BMJ Case Reports today and you can:

- Submit as many cases as you like

- Enjoy fast sympathetic peer review and rapid publication of accepted articles

- Access all the published articles

- Re-use any of the published material for personal use and teaching without further permission

For information on Institutional Fellowships contact consortiasales@bmjgroup.com

Visit casereports.bmj.com for more articles like this and to become a Fellow 